A N N A LES

UNIVERSITATIS MARIAE CURIE-SKŁODOWSKA

LUBLIN - POLONIA

VOL. LXIX, 1

SECTIO B

2014

Faculty of Earth Sciences and Spatial Management, Maria Curie-Skłodowska University

WALDEMAR KOCIUBA

\title{
Application of Terrestrial Laser Scanning in the assessment of the role of small debris flow in river sediment supply in the cold climate environment
}

\footnotetext{
Wykorzystanie naziemnego skaningu laserowego do oceny roli małych spływów błotno-gruzowych w zasilaniu rumowiska rzecznego w środowisku klimatów chłodnych
}

Keywords: debris flow, gravel-bed proglacial river, river sediment, erosional channel, accumulative fan, Spitsbergen

Słowa kluczowe: spływy błotno-gruzowe, żwirodenna rzeka proglacjalna, rumowisko rzeczne, rynna erozyjna, stożek akumulacyjny, Spitsbergen

\section{INTRODUCTION}

In the conditions of rapid transformations of the environment of the Arctic morphoclimatic zone, involving common retreat of glaciers and permafrost degradation (Pękala, Repelewska-Pękalowa 2007; Marsz et al. 2011), monitoring the rate of transformations of landforms becomes an important research task, permitting the quantitative and qualitative assessment of the dynamics of transformations and directions of their further development (Kociuba et al. 2013). The estimation of the dynamics of modern transformations of slope and valley landforms, and particularly the quantitative assessment of the occurring processes, requires the application of new research strategies and precise measurement tools (Teza et al. 2007, 2008; Travelletti et al. 2008). The precision and universal character of the applied measurement techniques are particularly important in areas subject to dynamic transformations, such as valley bottoms, glacier forefields, slopes subject to mass movements, solifluction slopes, or debris flow. Repeated high precision measurements permit both the qualitative and quantitative assessment of the rate of relief transformations (Kociuba et al. 2013), as well as the estimation of the 
degree of the threat of occurrence of extreme events (Kenner et al. 2011). Excellent confirmed results are ensured by the application of Terrestrial Laser Scanning (TLS) in research on land relief changes (Fischer, Huggel 2008; Teza et al. 2007, 2008; Travelletti et al. 2008; Rabatel et al. 2008; Oppikofer et al. 2009; Kenner et al. 2011; Kociuba et al. 2013). Environmental studies applying laser measurement techniques conducted so far emphasise the role of selection of the appropriate measurement strategy (Abbelán et al. 2009; Kenner et al. 2011), and the implementation of normalised methods of surface area and volume analysis for the purpose of obtaining better comparability of results (Lichti et al. 2005; Kociuba et al. 2013). One of the objectives of this paper was to present the application of TLS in geomorphological research as an effective tool of spatial analyses. A complex of erosion-deposition landforms typical of the Arctic morphoclimatic zone was selected as the study object, with features of small debris flow, constituting a connection between the slope sub-systems and proglacial river valley bottom (Kociuba et al. 2013). The quantitative and qualitative assessment of spatial transformations of landforms accompanying the development of the subsystem in melt seasons 2010-2013 contributes to a more thorough identification of their genesis and their development processes.

\section{STUDY AREA}

The assessment of the role of small debris flow in river sediment supply concerned the Scott River catchment located in the NW part of the Wedel-Jarlsberg Land, in the Bellsund region of Spitsbergen (Fig. 1). The Scott River catchment has an area of $10 \mathrm{~km}^{2}, 4.0 \mathrm{~km}^{2}$ of which is occupied by a valley glacier in the recession phase (Fig. 1). Its highest parts reach $600 \mathrm{~m}$ a.s.1., and its terminus reaches $90 \mathrm{~m}$ a.s.l. (Zagórski et al. 2008; Kociuba and Janicki, 2013).

The catchment is drained by the Scott River with a glacial-nival regime dominated by proglacial waters $(90 \%)$. Secondary sources of alimentation are nival water (4\%), rain water (4\%), and permafrost water (2\%) (Bartoszewski 1998). The glacier-free part of the catchment along a section of approximately $3.1 \mathrm{~km}$ is occupied by the Scott River valley (Fig. 1B). The relief of this section of the valley includes three clearly distinguishable parts separated with narrowings with a character of a gorge (Kociuba, Janicki 2013a).

\section{CONDITIONS OF DEVELOPMENT OF EROSIONAL SLOPE LANDFORMS}

The analysed complex of erosion-deposition landforms with features of debris flow is located in the lower course of the middle part of the valley, between 


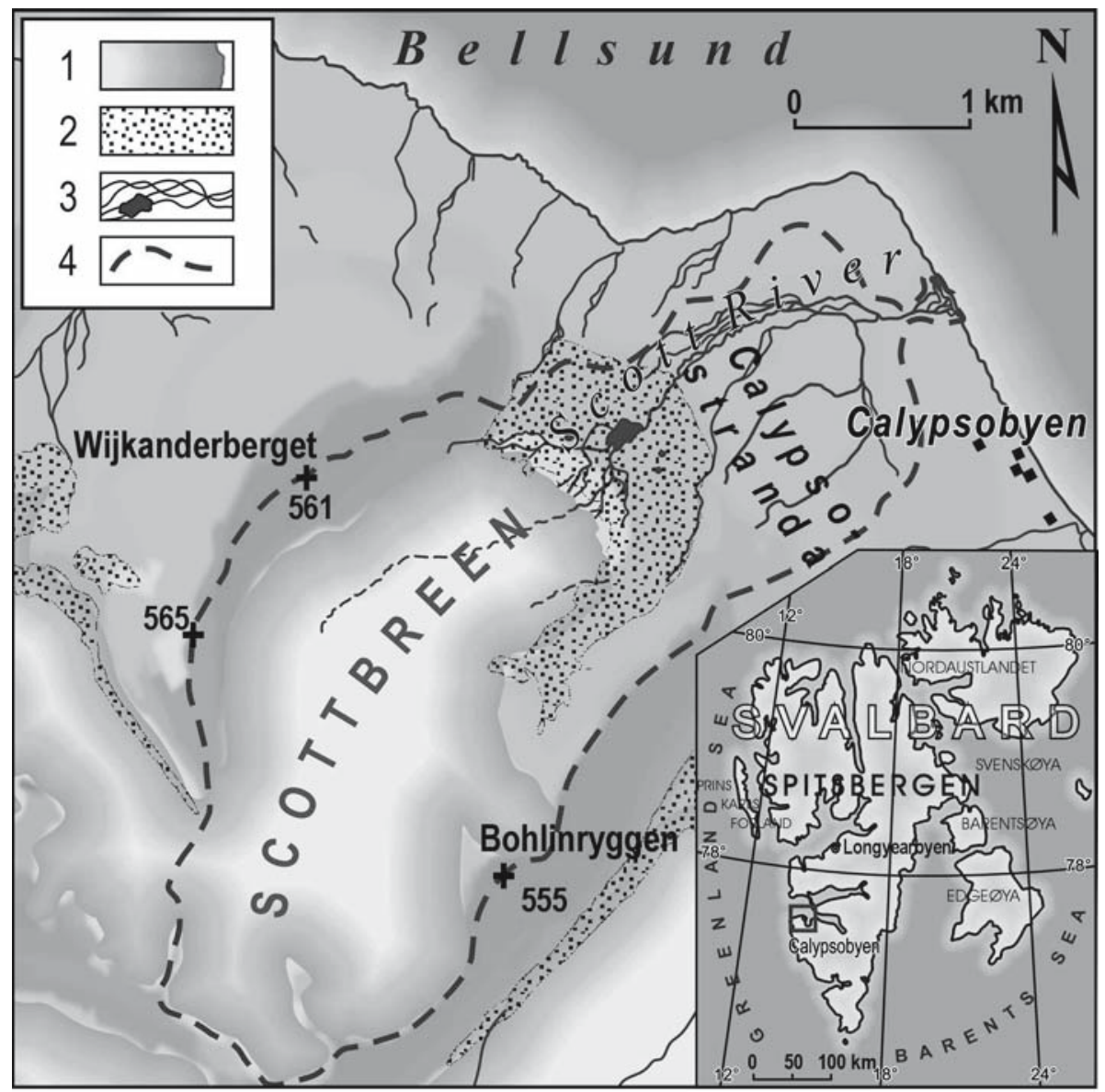

Fig. 1. Location of the study area in Spitsbergen. The analysed area of the Scott River catchment: 1. valley glacier, 2. glacial accumulation zone, 3. rivers and streams, 4. catchment boundaries

the zones of the Scott River gorges through the terminal moraine rampart (in the upper course), and the zone of the gorge through the elevated marine terraces (in the lower course). The middle section of the valley with a length of approx. $1.5 \mathrm{~km}$ occupies the wide (approx. $200 \mathrm{~m}$ ) glacier-free bottom developed by a braided river system with specific variable channel configuration. The study object is located on the right slope of the valley exposed to the north, above the mouth of the largest right-bank tributary of the Scott River, namely the Reindeer Stream (nival-permafrost regime), draining the eastern part of Calypsostranda (Bartoszewski 1998) (Fig. 2).

The slopes of the middle part of the valley have the character of a low (from several to a dozen metrers) erosional scarp with shallow erosional dissections, 


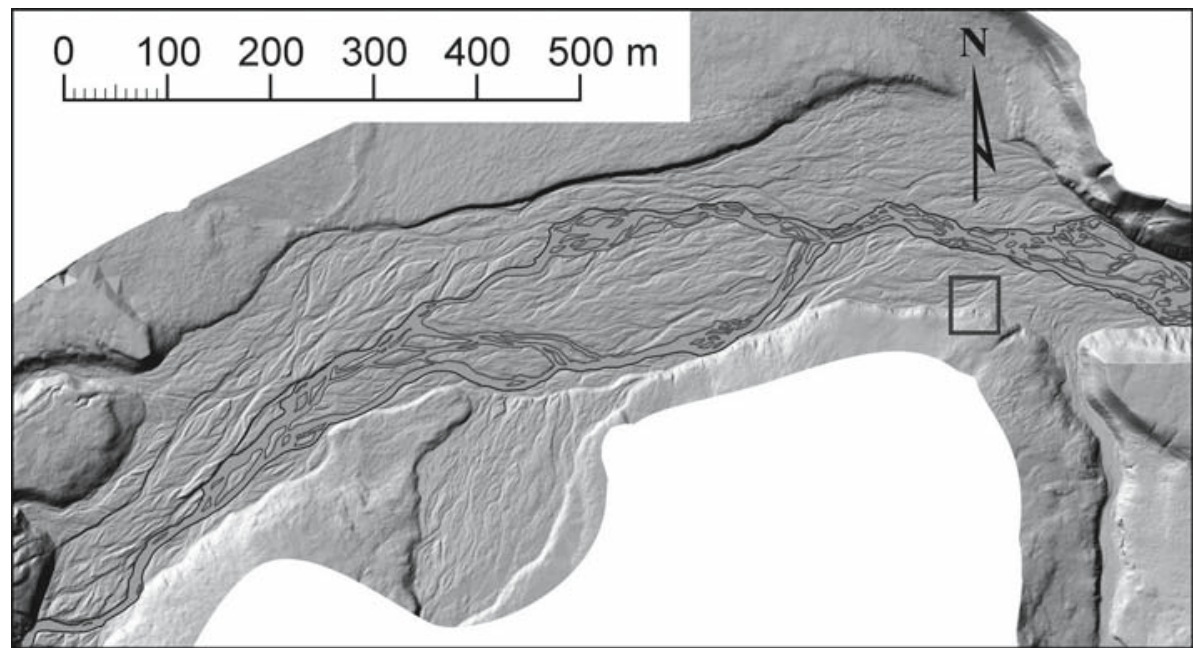

Fig. 2. Location of the study object in the middle section of the Scott River catchment

periodically modelled by cryogenic and solifluction processes (Kociuba et al. 2013). The complex of erosion-deposition landforms typical of the zone developed in the zone of the contact of the slope and valley bottom subsystems. The initial erosional landform developed on the extension of cracks in the frost polygons of the northern slope of Calypsostranda (Fig. 3).

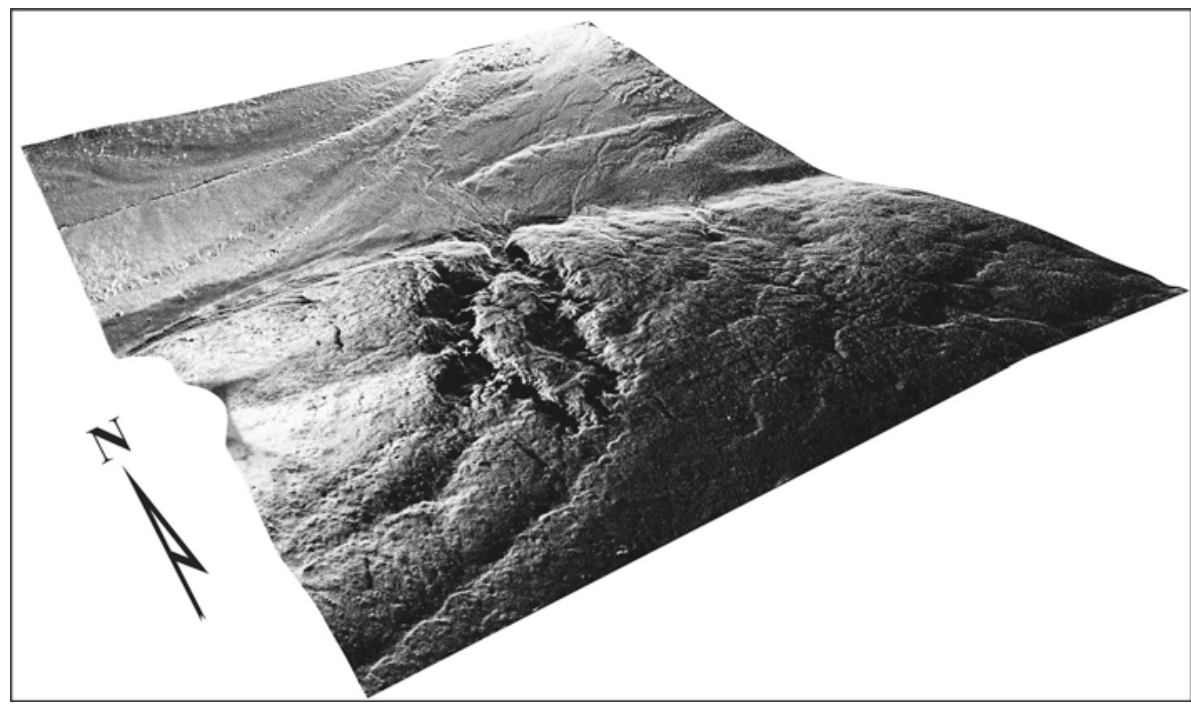

Fig. 3. A perspective 3D model of the northern slope of Calypsostranda. Development of the complex of erosion-deposition landforms on the extension of the cracks in frost polygons 
The development of the landform was initiated by a rapid flow of slope mud-debris covers with features of debris flow, resulting from the simultaneous occurrence of intensive permafrost deglaciation, an increase in the thickness of the active layer, and its saturation with precipitation water and melt water. The duration of this type of violent geomorphological events initiating the appearance or further development of landforms in the Scott catchment, is usually restricted to several (2-3) days. Such events usually correspond to the culmination of the melt season in the first half of July, and high intensity of rainfall increasing the rate of melting of the last snow patches in the niches of northern slopes. The violent character of flows is suggested by: the irregular shape and steep edges of erosional landforms, relatively high depths (up to several tens centimetres), and fine-fraction material deposited both in the bottom of the erosional landform and within the accumulative fan (Fig. 3). Several days of intensive debris flow, resulting in transport of a high amount of slope material and its deposition in the valley bottom in the form of an accumulative fan, are followed by a period of limited activity when the landform is transformed by weakly intensive solifluction (flows) and outwash processes (particularly the fan).

The location of the accumulative fan in the zone of flood distribution channels and at a considerable distance (approx. $70 \mathrm{~m}$ ) from the active fluvial system results in the limited role of the subsystem in the distribution of material to the channel. Effective supply of material to river sediment is only limited to the culmination of the largest floods during which distribution channels are activated (Fig. 4). During that time, a substantial part of material deposited within the accumulative fan is removed, and supplied to river sediment by means of distribution channels.

\section{STUDY METHODS}

The assessment of the role of small debris flow in river sediment supply in polar conditions involved the application of the Terrestrial Laser Scanning (TLS) technology. The comparative field research was conducted at the turn of July and August 2010 and 2013 by means of a LeicaScanStation C10 laser scanner. The applied type of the scanner permits stationary laser distance measurement by means of green pulse laser (with a wavelength of $532 \mu \mathrm{m}$ ) with a velocity of up to $50,000 \mathrm{pt} \mathrm{s}^{-1}$, and at a maximum distance of $300 \mathrm{~m}$.

The measurement data obtained in the form of a point cloud constitute model spaces with an accuracy of their 3D location of up to $6 \mathrm{~mm}$ (distance of $4 \mathrm{~mm}$ ). Transformed to a Digital Terrain Model (DTM), they permit multi-aspect analyses of the studied landform, including detailed 3D measurements or analyses of its cross- and longitudinal sections. The predefined resolution of measurement, 


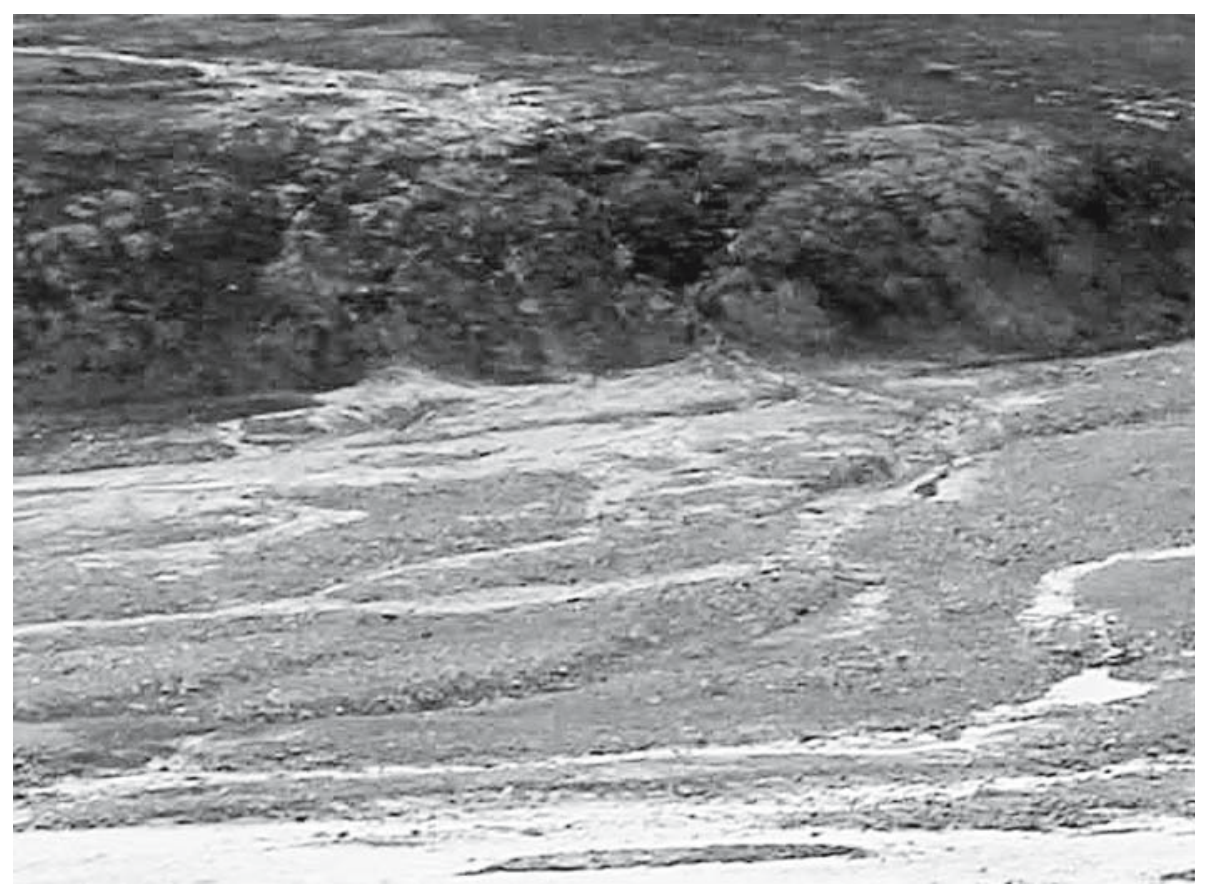

Fig. 4. Washing of the accumulative fan by active distribution channel during the culmination of Scott River flood in August 2013

determining the number of single measurements, is of primary importance for the interpretative possibilities of the obtained model. In this case, medium resolution was applied $(0.1 / 0.1 \mathrm{~m}$ per $100 \mathrm{~m})$, permitting obtaining an average of approx. 5 million point measurements at each of the measurement sites.

\section{STRATEGY, ORGANISATION, AND SCOPE OF MEASUREMENTS}

The DTM quality depends equally on the technical possibilities of the measuring device, and on the applied strategy and organisation of the measurement itself. The application of a medium-range scanner in the measurement of large spatial objects requires multi-site measurements. The interpretative possibilities of the resulting model are determined by the accuracy of integration of point clouds obtained from particular measurement sites. Due to the lack of permanent, characteristic spatial elements and reference points in the study area, it was not possible to apply one of the most popular methods of model integration, namely so-called C2C (cloud to cloud), also known as the "iterative closest point (ICP)" method (Besl, McKay 1992; Chen, Medioni 1991). During the survey of 2010, a method of permanent target points (TP) was applied, ensuring very high accuracy 
(Kociuba et al. 2013). The measurements in the study area involve the establishment of a network of permanent, marked target points, distributed in the apices of a polygon. At each of the target points, normalised targets are placed, identified by the device's interface during the scanning process. The scanner is placed in a convenient place selected by the operator. The determination of the location of the scanner in relation to a minimum of two target points common for adjacent scenes permits precise integration of particular point clouds, and obtaining the expected accuracy of the model space. The determination of the location of at least four of the used target points by means of GPS Leica System 500 satellite positioning permitted the transformation of the model from the local to the geographic system. During the survey of 2013, the modified TP method was applied, i.e. measurement of a point with known coordinates oriented to the network of permanent control points with known coordinates (KC). The measurement based on a network of points with known coordinates required prior permanent marking of points of the planned location of the scanner, as well as reference points (they were applied interchangeably). The determination of the location of the $\mathrm{KC}$ point network was based on satellite positioning by means of the GPS RTK TopConHipper II system. Although the $\mathrm{KC}$ methods required a precise (with accuracy of $1 \mathrm{~mm}$ ) determination of the location of the scanner at the measurement site, the orientation of the scanner was only based on one reference point. This made the measurements substantially more efficient than by the traditional TP method. As a result of the application of the $\mathrm{KC}$ measurement strategy, the measured points already had geographic coordinates during the scanning process. Such organisation of measurements largely reduced the time of interpretation of results. The time-consuming process of transformation from the local to geographic system, and the "manual" integration of particular scans were avoided. The LeicaCyclone 8.0 software used for DTM integration automatically combines georeference model spaces obtained by means of this method into one $3 \mathrm{D}$ model.

\section{STUDY RESULTS}

\section{Model parameters and data analysis}

The effect of the measurements was the development of an integrated DTM obtained from the integration of particular model spaces where the number of measurements in combined point clouds amounted to approx. $5 \mathrm{M} \mathrm{pt}$. The applied TP and KC methods permitted precise combining of particular point clouds into a target model with the total error not exceeding $\pm 9 \mathrm{~mm}$, by means of the LeicaCyclone 8.0 software. The resulting integrated 3D space, composed of approx. $20 \mathrm{M}$ pt., was used for the development of a Digital Terrain Model (DTM), constituting the basis for further quantitative and qualitative analyses. 


\section{The application of the model for the assessment of the dynamics of relief transformations}

The analysed landform is an erosional dissection typical of the slopes of the Scott River valley, with an accumulative fan causing valley bottom aggradation. In its middle section, the Scott River forms a valley bottom with a width from $200 \mathrm{~m}$ to $250 \mathrm{~m}$, dissecting the area of Calypsostranda. The valley slopes in this part have the character of an erosional cliff with a height from $1 \mathrm{~m}$ to $8 \mathrm{~m}$, dissected by shallow erosional cuts, frequently with a character of small debris flow (Fig. 5). The assessment of the role of such landforms in supplying river sediment and development of the proglacial river valley bottom in the conditions of increased dynamics of deglaciation processes was performed based on the comparative analysis of changes in the physical parameters of the analysed landforms in the period from 2010 to 2013 (Fig. 5).

The study object is a typical erosional dissection located on the right slope of the main valley in the vicinity of the mouth of the Reindeer Stream. Erosional landforms of the type, with an accumulative fan at the base, are developed in the period of activity of the permafrost active layer. The analyses of the physical parameters of the studied landforms involved the application of the Digital Terrain Model (DTM) developed based on a network of triangles with a side of $0.05 \mathrm{~m}$. The surface of the valley slopes with an inclination of $35^{\circ}$ was adopted as the reference surface. The lower reference surface was the Scott River valley bottom. In 2010, the erosional part of the study object was composed of a bipartite inter-colluvial depression with a width of up to $8 \mathrm{~m}$, dissected with a system of erosional channels with a total length of $10 \mathrm{~m}$, dissecting the scarp of the valley slope with a height of $3 \mathrm{~m}$ (Kociuba et al. 2013).

The accumulative part of the study object was composed of an accumulative fan with a length of $5 \mathrm{~m}$ and base width of $15 \mathrm{~m}$, causing aggradation of the Scott River valley bottom. The analysis of the volume of the landforms, performed in the LeicaCyclone 8.0 software, showed that the volume of material discharged during the development of the erosional landforms amounted to $18 \mathrm{~m}^{3}$. The volume of material deposited in the form of the fan amounted to $23 \mathrm{~m}^{3}$. The analysis of the model of 2013 shows a considerable increase in the size of the erosional part. The maximum width of the inter-colluvial depression did not increase substantially, but in the upper part, the bipartite (in 2010) depression was combined into one landform with a width of $8 \mathrm{~m}$. The erosional channels were also substantially elongated and straightened (Fig. 5). The volume of material deposited in the accumulative fan causing aggradation of the Scott River valley bottom considerably decreased in spite of retaining its size from 2010 in the plan. The volume of material discharged during the development of the erosional landforms increased to $29.4 \mathrm{~m}^{3}$, and that of material deposited in the fan decreased to $18.2 \mathrm{~m}^{3}$. The 

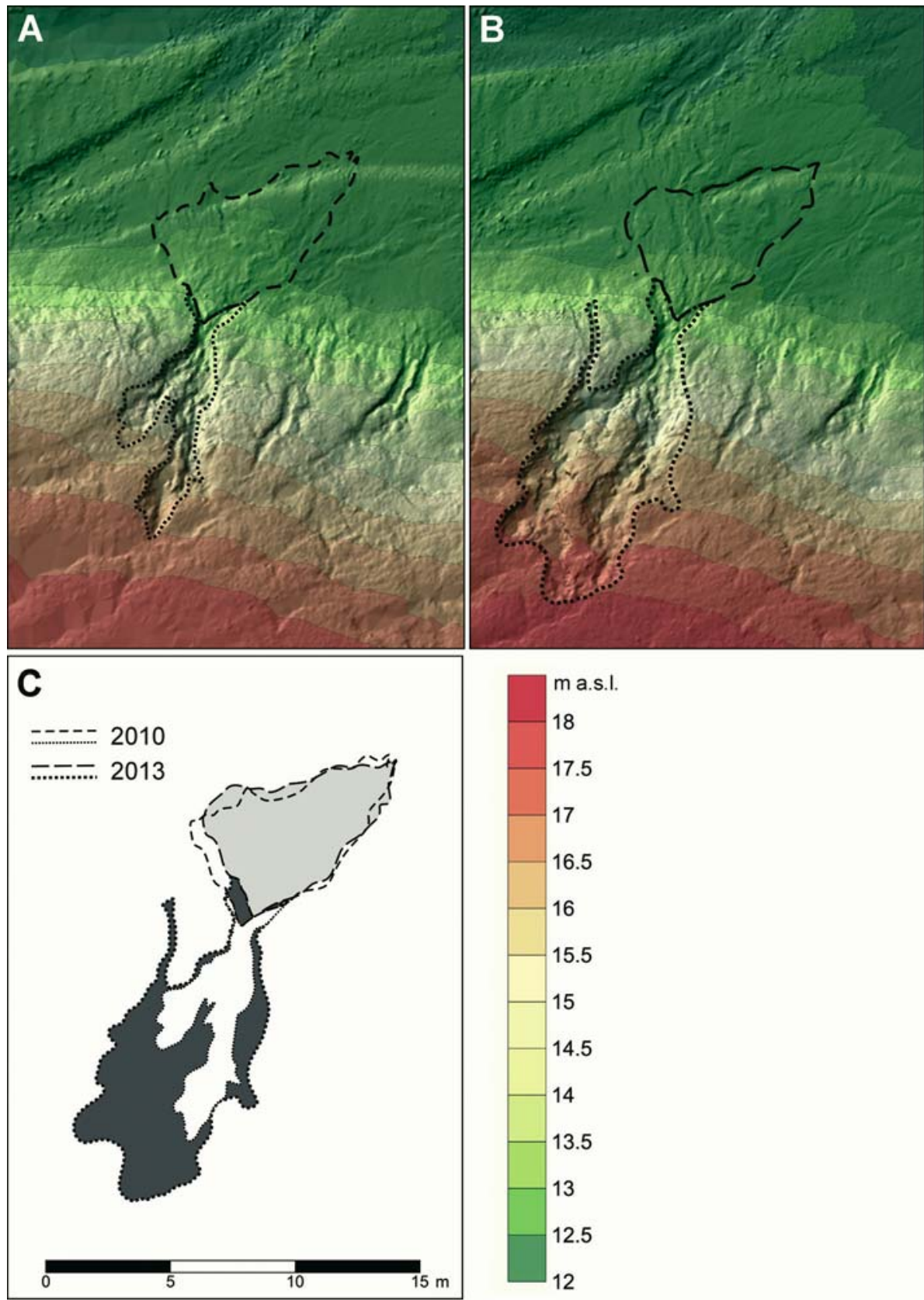

Fig 5. Erosional dissection with the accumulative fan: A - during 2010, B - during 2013, C - draft of changes 2010-2013 
total volume of discharged material in the period from 2010 to 2013 amounted to $16.1 \mathrm{~m}^{3}$.

The prevalence of the volume of material deposited in the fan in 2010 suggests the young age of the landform. The $16 \%$ prevalence of the volume of the erosional over the accumulative part probably results from a change in volumetric density as a consequence of active mass processes (Kociuba et al. 2013). During violent debris flow, the coherence of transported material is lost, resulting in the prevalence of the volume of the depository landform. Similar correlations, manifested in a 7\% prevalence of the estimated volume of erosional over accumulative landforms, were determined in the case of two debris flow events in Halltal (the Austrian Alps) (Bremer and Sass 2012). The authors describing debris flow in the Alps, however, provided no interpretation of the determined disproportion.

In 2013, the volume of the erosional part of the landform increased by $63 \%$ in relation to 2010 . This is a natural consequence of the development of the landform during three consecutive melt seasons. A reduction by $21 \%$ in the volume of material deposited in the form of an accumulative fan in the Scott River valley bottom suggests periodical washing out of the landform. Due to the peripheral location of the fan in relation to the active channel zone, the redeposition of material from the fan, and its supply to the river sediment can only occur during the culmination of the largest floods when discharge in the distribution channels is activated.

\section{CONCLUSIONS}

- The Scott River catchment, subject to dynamic transformations related to the retreat of the valley glacier and permafrost deglaciation, constitutes an interesting study object. The performed measurements introduce a new quality in the spatial analyses of the area.

- The assessment of the rate of transformations and directions of development of erosional-depositional landforms was performed with the application of TLS. The obtained DTM permitted the qualitative and quantitative analysis of spatial transformations.

- The conducted detailed spatial analyses of the surface of the bottom and slopes of the Scott River valley confirmed high precision and effectiveness of TLS as a tool of monitoring of the dynamics of transformations of landforms of varied character, size, and genesis. The adopted measurement strategies ensured a high resolution of the obtained models of the analysed surfaces.

- The applied measurement technique provides incomparably better possibilities of detailed analysis of changes in the physical parameters of landforms than the traditional techniques applied so far. The universal character, simplicity of use, and the amount of data provided during one measurement cycle incomparable with the traditional methods, as well as the comparability of results, should consti- 
tute the basis for the implementation of TLS as the basic tool of the new complex approach to geomorphological studies.

- In geosystems subject to rapid transformations, cyclical measurements permit the monitoring of the rate of the occurring land relief transformations. Repeating the measurements in consecutive years permitted the determination of both the spatial and temporal dynamics of the occurring transformations, and became the basis for the development of the model of transformations of small debris flow in the conditions of proceeding cryosphere degradation.

- A relevant selection of parameters of the models permitted the determination of the degree of connection of the slope and valley subsystems, and the estimation of the amount of material deposited in the valley bottom.

- A $16 \%$ prevalence of the volume of the erosional over the accumulative part was revealed in 2010. It resulted from a change in the volumetric density as a consequence of active mass processes. The disproportion in the erosionalaccumulative balance can be treated as an indirect indicator of the young age of the landform and its genesis (debris flow).

- It was evidenced that as a result of the development of the landform during three consecutive melt seasons, the volume of the erosional part increased by $63 \%$, and in the accumulative part (fan), it was reduced by $21 \%$. A discharge of $16 \mathrm{~m}^{3}$ of debris suggests periodical intensive washing out of the landform during floods.

- During the time, a large portion of material deposited within the accumulative fan is discharged. The material is supplied to the Scott River sediment by means of the distribution channels.

\section{ACKNOWLEDGEMENTS}

The field research with the application of TLS was conducted during the $22^{\text {nd }}$ and $25^{\text {th }}$ Polar Expedition of UMCS researchers to Spitsbergen. I would like to thank all of the participants of the expeditions for their assistance in conducting measurements, as well as for comments and discussions helpful in the interpretation of the results. I would particularly like to thank MSc. Eng. Waldemar Kubisz and the management of Leica Geosystems Polska for providing the measurement equipment in 2010 and active participation in both the research and development of the model. The Measurement campaign 2013 was financed from the funds of the project of the National Science Centre 2011/01/B/ST10/06996 "Mechanisms of fluvial transport and sediment supply to channels of Arctic rivers with various hydrological regimes (SW Spitsbergen)", and with the support of the project POIG.01.03.02-00-082/10 "Covering the device for measuring bedload transport rate in river channels with European patent protection". 


\section{REFERENCES}

Abbelán A., Jaboyedoff M., Oppikofer T., Vilaplana J.M., 2009: Detection of millimetric deformation using a terrestrial laser scanner: experiment and application to a rockfall event. Natural Hazards and Earth System Sciences, 9, 365-372.

Bartoszewski S., 1998: Reżim odpływu rzek Ziemi Wedel Jarlsberga (Spitsbergen). Wydawnictwo UMCS, Lublin, $167 \mathrm{p}$.

Besl P., McKay N., 1992: A method for registration of 3-D shapes. IEEE Transactions on Pattern Analysis and Machine Intelligence, 14, 239-256.

Bremer M., Sass O., 2012: Combining airborne and terrestrial laser scanning for quantifying erosion and deposition by a debris flow event. Geomorphology, 138, 49-60.

Chen Y., Medioni G., 1991: Object modeling by registration of multiple range images. IEEE International Conference on Robotics and Automation, 3, 2724-2729.

Fischer L., Huggel C., 2008: Methodical design for stability assessments of permafrost-affected high-mountain rock walls. In: Kane, D.L., Hinkel, K.M. (eds.), $9^{\text {th }}$ International Conference on Permafrost, Institute of Northern Engineering, Fairbanks, Alaska, 439-444.

Harasimiuk M., Król T., 1992: The dynamics of morphogenetic and sedimentary processes in the estuary segments of river valleys in the Recherche Fiord (Western Spitsbergen). In: J. Repelewska-Pękalowa, K. Pękala (eds.), Spitsbergen Geographical Expeditions, Arctic Natural Environment Problems, MCSU Press, Lublin, 59-66.

Kenner R., Philips M., Danioth C., Denier C., Thee P., Zgraggen A., 2011: Investigation of rock and ice loss in a recently deglaciated mountain rock wall using terrestrial laser scanning: Gemsstock, Swiss Alps. Cold Regions Science and Technology, 67, 157-164.

Kociuba W., Janicki G., 2014: Continuous measurements of bedload transport rates in a small glacial river catchment in the summer season (Spitsbergen). Geomorphology, 212, 58-71.

Kociuba W., Kubisz W., Zagórski P., 2014. Use of terrestrial laser scanning (TLS) for monitoring and modelling of geomorphic processes and phenomena at a small and medium spatial scale in Polar environment (Scott River - Spitsbergen). Geomorphology, 212, 84-96.

Kociuba W., Janicki G., 2013a: Fluvial Processes. In: P. Zagórski, M. Harasimiuk, J. Rodzik (eds.), The Geographical Environment of NW Part of Wedel Jarlsberg Land (Spitsbergen, Svalbard), Wydawnictwo UMCS, Lublin, 192-211.

Marsz A.A., Pękala K., Repelewska-Pękalowa J., Styszyńska A., 2011: Zmienność maksymalnej miąższości czynnej warstwy zmarzliny $w$ rejonie Bellsundu (W Spitsbergen) w okresie 19862009. Problemy Klimatologii Polarnej, 21, 133-154.

Oppikofer M., Jaboyedoff T., Blikra L., Derron M.H., Metzger R., 2009: Characterization and monitoring of the Aknes rockslide using terrestrial laser scanning. Natural Hazards and Earth System Sciences, 9, 1003-1019.

Pękala K., Repelewska-Pękalowa J., 2007: Dynamics of active layer of permafrost. Landform Analysis, 5, 168-169.

Rabatel A., Deline P., Jaillet S., Ravanel L., 2008: Rock falls in high-alpine rock walls quantified by terrestrial LiDAR measurements: a case study in the Mont Blanc area. Geophysical Research Letters, 35, L10502.

Teza G., Galgaro A., Zaltron N., Genevois R., 2007: Terrestrial laser scanner to detect landslide displacement fields: a new approach. International Journal of Remote Sensing, 28, 3425-3446.

Teza G., Pesci A., Genevois R., Galgaro A., 2008: Characterization of landslide ground surface kinematics from terrestrial laser scanning and strain field computation. Geomorphology, 97, 424-437.

Travelletti J., Oppikofer T., Delacourt C., Malet J.-P., Jaboyedoff M. 2008: Monitoring landslide displacements during a controlled rain experiment using a long-range terrestrial laser scan- 
ning (TLS). International Archives of the Photogrammetry, Remote Sensing and Spatial Information Sciences, 37 (B5), 485-490.

Zagórski P., Siwek K., Gluza A., Bartoszewski S., 2008: Changes in the extent and geometry of the Scott Glacier, Spitsbergen. Polish Polar Research, 29, 163-185.

\section{STRESZCZENIE}

W artykule omówiono rolę jaką spełniają niewielkie spływy błotno-gruzowe w zasilaniu rumowiska rzecznego oraz kształtowaniu dna doliny rzeki proglacjalnej w warunkach wzmożonej dynamiki procesów deglacjacji. Ocenę tempa przekształceń form stokowych i dolinnych wykonano przy użyciu naziemnego skaningu laserowego (TLS). Pozwoliło to na precyzyjne odwzorowanie powierzchni terenu oraz ocenę przestrzennych zmian jakościowych i ilościowych. W opracowaniu porównano wyniki pomiarów terenowych (z lat 2010 i 2013) wykonanych w dolnym odcinku doliny rzeki Scotta, położonej w NW części Ziemi Wedel Jarlsberga (Spitsbergen). W obu przypadkach do pomiarów wykorzystano technologię skanowania laserowego 3D. Pomiarami objęto fragment południowego zbocza niezlodowaconej części dna doliny Scotta, położony w sąsiedztwie ujścia głównego prawobrzeżnego dopływu - Potoku Renifera. W pomiarach zastosowano stacjonarny skaner laserowy średniego zasięgu Leica Scan Station C10. Kompleksowe pomiary dna doliny wykonano z trzech wzajemnie powiązanych stanowisk pomiarowych. Na każdym ze stanowisk uzyskano chmurę punktów tworzących „model przestrzeni” złożony z 5 milionów punktów pomiarowych, z połączenia których uzyskano cyfrowy model powierzchni terenu (DSM) o dokładności $( \pm 0.9 \mathrm{~cm})$. Szczegółowość modelu pozwoliła na wykonanie precyzyjnych pomiarów parametrów omawianych form. Analiza modeli 2010 i 2013 wykazała intensywny rozwój małych spływów błotno-gruzowych, przejawiający się przyrostem objętości niszy osuwiskowej o $63 \%$, przy jednoczesnym $21 \%$ ubytku materiału zdeponowanego w stożku akumulacyjnym. Dysproporcja ta świadczy o włączaniu materiału zdeponowanego w obrębie stożka w obieg rumowiska rzecznego. Położenie stożka w strefie powodziowych koryt rozprowadzających ogranicza czas jego rozmywania jedynie do kulminacji największych wezbrań. Przedstawiona analiza dynamiki rozwoju małych spływów błotno-gruzowych i ich znaczenie dla obiegu materii może przyczynić się do lepszego zrozumienia przebiegu procesów kształtujących zlewnie w warunkach klimatu zimnego. 